\title{
THE EDITOR
}

\section{INTRODUCTION \\ ON SOME REFLECTIONS ON PUBLIC SERVICE TRANSLATION}

\section{Carmen Valero-Garcés \\ University of Alcalá, Spain \\ carmen.valero@uah.es}

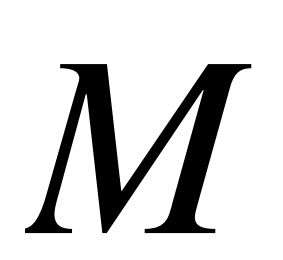

ore than a decade ago (2002), the article "Traducir de y para los que llegan: una incipiente realidad" ('Translating from and for New Arrivals: An Emerging Reality") (Valero-Garcés, 2002), spoke about the lack of interest and relevant studies about translation-understood as the written transfer of a text from one language to another-within the thenemerging field of Public Service Translation and Interpreting (PSIT) or Community Interpreting. We said it was a neglected area compared to the interest in interpreting for publications, seminars, workshops or specific conferences like Critical Link. This situation does not seem to have changed much, in line with comments by researchers and teachers, as well as their continuing efforts to draw attention to this issue. One only needs to glance at the number of publications derived from Critical Link conferences (Brunette et al. 2003; Wadensjö et al. 2007; Hale et al. 2009; Schäffner et al. 2013) or other conferences organized by the research group FITISPos (Training and Research in Public Service Translation and Interpreting) over these past years (Valero Garcés et al., 2002, 2005, 2008, 2011, 2014).

The idea of devoting Volume 2 of FITISPos International Journal to an unexplored topic with limited material began considering these aspects and from certain elements that caught our attention at the time. First, it was the creation of two associations directly related to TISP: European Network in Public Service Interpreting and Translation (ENPSIT) and the Asociación de Formadores, Investigadores y Profesionales en Traducción e Interpretación en los Servicios Públicos ("Association of Teachers, Researchers and Professionals in Public Service Translation and Interpreting') (AFIPTISP) in which the term 'translation' was included.

The second component was the European Commission-sponsored conference Translating and interpreting for our citizens (March 2014), which met for the first time at the Directorate General for Translation (EU DGT), the Directorate General for Interpretation (DG Interpretation, SCIC) and the different agencies involved in the preservation of multilingualism. Its aim was to foster teamwork and to go a step further in communication policy with lesser used languages, due to in part by widespread immigration throughout the EU.

The third element was the assembly of several events sharply focused on translation. We specifically refer to two conferences: one organized at the University of Westminster, 
London, UK, titled Translating cultures: translation as a tool for inclusion/exclusion in a multicultural society in June of 2014, and the other one at the University of Western Sydney, Australia, titled Community Translation in September of 2014.

The main topics of the Sydney and UK conferences draw attention to the complexity of translation and the variety of necessary studies: linguistic and Public Service Translation (PST), policy, translation and inclusiveness, sociocultural diversity and translation, ideology and PST, power relations: translating vs. empowerment, translating to and from minority languages, translation quality in public services, and PST training. Additionally, the titles of some of the presented papers on this topic give an account of the interest and the need for further research in TSP:

- "Translation as a Communication Tool in the Police Environment" (Katrina Mayfield);

- 'Challenges in Defining 'Community' for Community Translation" (Daniel Tomozeiu);

- "Community Translation: An Examination of Practice and Praxis" (Brooke Townsley);

- "Language Policy and Public Service Translation: The Case of European Multilingualism" (Catherine Vieilledent-Monfort);

- "Translation and Language Ideologies" (Abigail Pita).

The main objective of PST is to directly communicate specific information (on health, education, administration, society, etc.) to a specific audience: a public - as in the case of interpretation-which meets the requirements of a cultural and linguistic minority, who generally has a lower education and purchasing power than the majority and who often is unaware or does not dominate the social reality of their adopted country. Additionally, as Roberts (1997: 12) states, minority culture is not always understood by the majority group (even more so than in terms of language) who organizes and provides services to those clients. In other words, the objective is to adapt a text to the needs of a minority that lives in a country with a dominant majority (Valero Garcés, 2002: 63).

Tomozeiu (2014) gives a similar definition on the importance of other underappreciated elements of translation, moving away from the "what" and the "how":

\footnotetext{
'Public service translation' (also known as 'Community translation') is emerging as an important, distinct subfield in translation studies. Its focus on the translation of texts produced by public services for the benefit of speakers of less-established languages makes it good role relevant research area in today's globalizing world. In a multicultural society decisions about what is translated and how the translation is done far-reaching have implications for the inclusion and exclusion of uncertain communities and/or community members.
}

Considering these elements, we are led to think about how the process of translation is initiated (who requested the translation) and the executor of the action itself (the translator) (Nord, 1997). Regarding the first point, it usually coincides with the service provider: institutions, NGOs, associations, government offices, hospitals, schools, etc., which request translations of a variety of texts with very different qualities and complexities (from a birth certificate to a lease, for example). This also has implications for the translator, which we will discuss further on. 
The literature on PSIT provides examples of the interpreter's work (Bolden, 2000; Angelelli, 2004; Erlt and Pöllabauer, 2010). However, we could barely find any studies about translators, which again raises many questions: is the translator a sociocultural mediator with specific skills and proper training that goes beyond the knowledge of languages (or dialects) and cultures? Is a good command of intercultural competence required? Why? What, if any, influence is there between working with two languages, one of which usually has a lower social status compared to the other, which belongs to the dominant culture? How can certain neutrality and distance be ensured, even when working for their (the translator's) same ethnic community? How can awareness be raised about the lack of education or about cultural differences between the two communities? What ability must be developed so that the communication professional may serve as a linguistic and cultural bridge when dealing with specific topics that may be taboo for some communities? Should he/she know work-related terminology? What kind of texts should be translated? If the goal is to communicate, should the professional be able to change their register or adapt the text to the needs of the host community, etc.?

Translators also come up against the scant recognition that this profession has, which leads to translation being a low-paid job that often keeps its practitioners from access to available training. Surprisingly, despite the large number of translation educational centers (in Spain alone, there are more than a dozen Translation and Interpretation Departments in universities), there are so few training options related to this subarea of Translation Studies (that being PST). This leads to another question: can PST be considered as specific translation?

The differences between specialized and general translation, according to Monterde Rey (2003: 107), are the following:

1. In specialized translation, the sender and receiver of the text belong to a specialized language.

2. The translator must know (or be able to find) the terminology used.

3. The translator must know (or be able to familiarize himself with) about the specialized subject.

We agree with such features as long as we are talking about professional translators/interpreters. Concerning TSP, in the attempt to encourage communication between such different participants, the translator undoubtedly works with specialized texts (e.g. medical treatments) in complex situations (e.g. application for registration), and therefore must be versatile (e.g. master the users' language, social conventions and/or text typology). Again, more questions arise: what about in the case of ad hoc volunteer translators/interpreters without training? How is terminology managed? What kind of documentation do they have access to? What strategies do they use to convey a certain concept or expression in the target language? How confident are they in their job? Is any particular preparation needed? If problems are detected, what happens if parallel documents, consulting experts or dictionaries and terminology banks are unavailable? How do volunteers and clients' family members serving as translators/interpreters handle this specialized language in our hospitals, healthcare centers, police stations or schools? Are there any specialized resources in minority languages in order to meet those needs? 
There are three main frameworks where terminology/specific languages are used in communication:

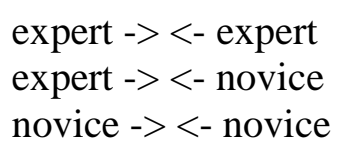

A third element can be added to this pairing for when speakers do not share the language and, thus, the following tripartite situations can be found:

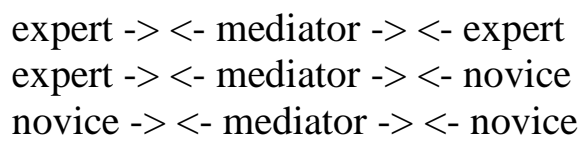

In the field of PSIT, communication between an expert and a novice is very common; take, for example, a doctor's appointment in which the doctor participates with an almost illiterate patient who does not speak Spanish and a mediator or third element that makes communication possible and who has to translate a brochure about stomach ulcer treatment.

Specialized language or terminology surrounds us in our daily life. We find it in any written document addressed to experts in a specialized field (e.g. articles in a scientific journal), but also in texts aimed at people who are inexperienced in a certain field (e.g. registration application forms, lawsuits, academic transcripts, employment contracts, brochures, etc.).

Teresa Cabré (2004: 101-102) also underlines that it is impossible to draw a defined line between the notion of what is general and what is specialized, which applies to any field related to knowledge or language. Here she gives three specific reasons:

1. Because most individuals' daily activities always take place in specialized areas, although the everyday nature of these activities makes it go unnoticed.

2. Because a permanent transfer between ordinary and specialized life occurs, resulting in the appearance of two opposing phenomena in the lexicon used to refer to reality: the transfer of general vocabulary units to specialized (terminologization) and the transfer of specialized terms to general (trivialization).

3. Because a subject may be at different levels of abstraction, with different communicative purposes in different communicative situations and for different language functions (Cabré, 2004: 102).

Again, further questions arise: if problems are detected, what happens if there are no parallel documents, experts to consult or dictionaries and terminology banks? What strategies are used to convey a concept or expression in the target language and how is terminology and documentation handled? The foreign population, as well as the service providers, make use of phrases and special terms in their daily contacts, terms which the translator must understand and translate in order to ensure that information is correctly transferred. Very often, this terminology is not found in common dictionaries. In fact, there may not be any dictionary containing the majority language and the language spoken by the minority (Valero 
Garcés et al, 2011). The translator must then resort to the same strategies used by the specialized translator, e.g. an omission, the use of an "approximate" or "provisional" equivalence, the explanation of the concept, the lending or the creation of new words entirely (Niska, 2003). In short, we could say that PST is a complex and hybrid case of specialized translation at the crossroads of many different factors and that it requires specialists and adequate training, as with any type of specialization.

In sum, there are many issues to explore and research papers published on public service translation. Hopefully, this subject will help fill the void in the field of PSIT and help raise visibility of this emerging area of Translation Studies. And, in echoing the multilanguage nature of this piece, articles in Spanish, English, Russian and Chinese are included.

Due to its awareness of this diversity of topics and approaches, FITISPos-IJ, vol 2, includes eight items sorted alphabetically by the author's first name.

The first chapter, in English, has been written by Ineke Creeze and Hanneke Lustig, under the title $A$ look inside the translators' workspace: Discussions around a large nursing text translation. The authors investigate about the challenges of translating texts, in this case nursing issues, for different communities in different countries (New Zealand and Belgium) and languages (Dutch - English). Their theoretical approach is based on the skopos theory and proposals for translating cultural terms.

The second article, written by Ula Idzikowski in English and entitled Public Service Translation in Flanders: On the continuous efforts to evolve from paraprofessionalism to professionalism, contributes to calling the attention to PST studies by providing an overview of the steps taken towards its professionalization in Flanders (Belgium) and the remaining challenges posed by the future of PSIT.

Ivona Ivanova Angelova is the author of the third article, and it is entitled Introducción al concepto de tortura como punto de partida para una base de datos (inglésespañol/ Introduction to the concept of torture as a starting point for a database (EnglishSpanish). she writes in Spanish about a new subject in PST, even though at first sight it might seem alien to this field. As we all know, translators and interpreters in PSIT must work in very different contexts and situations and they are in contact with people from different backgrounds and origins who might have suffered some kind of torture in their countries, while traveling or after arriving in police stations or customs. The article introduces the reader to the concept of torture by providing hints about its historical development, types of practices and places where it has been (and still is) practiced as the basis for a first draft glossary (English-Spanish). Attention is called to the lack of bilingual resources about this topic.

Mengshuan $\mathrm{Ku}$, in the fourth paper, takes us to another very different environment (Taiwan) and another language (Chinese) as an example of the diversity of topics in PST. Under the title 台北捷運營運資訊簡介」西班牙語版分析/Analysis of the translation of 'Taipei Metro Guide' on its Spanish version, Ku studies the multilingual context of public services in Taiwan and compares the Chinese and Spanish version of metro guide from the perspective of a Spanish speaker living in Taiwan. The main objective is to analyze the acceptability of the target text for new-comers attracted by the economic prosperity of this country.

Maneerat Marnpae, in the fifth article, titled La traducción funcionalista en los servicios públicos: un caso de materiales de apoyo del ámbito sanitario para la población inmigrante/Functionalism in translation in public services: support materials related to the 
healthcare setting for immigrants, anticipates that incorporating functionalist approaches in Translation Studies would be relevant to produce effective target texts and so she carries out an analysis of Spanish healthcare related materials for Thai users.

Moreover, Araceli Rojo Chacón, in La transposición al derecho nacional de la Directiva europea 2010/64/UE en España, Francia, Bélgica y Luxemburgo 'Lost in transposition'/The transposition of European Directive 2010/64/EU into national law in Spain, France, Belgium and Luxembourg: 'Lost in transposition', takes us to the legal field in order to display a comparative study of the situation of legal translators in Spain, France, Belgium and Luxembourg before the transposition of the Directive. Their situation is compared with the Austrian system. The study samples the differences and challenges that the different countries are facing in order to implement the Directive on issues such as the creation of a translator register to act in criminal proceedings.

Furthermore, Maria Shcherbakova in Конщептуальный подход к разработке глоссария по медицинской терминологии (русско-испанский)/Conceptual approach used in the development of a glossary of medical terms (Russian-Spanish)) written in Russian, focuses on terminological work in the medical field in a combination of languages - RussianSpanish- in which resources are almost non-existent. The aim is to create a glossary of terminology related to the cardiovascular system, after a comprehensive analysis of the problems posed by their translation. Her hypothesis is that, despite the Greek and Latin origin of most of the terms selected in Spanish and a large part of the terms in Russian, the literal translation of these represents the most serious and frequent errors due to the peculiarities of both medical systems (Spanish and Russian) in which terminology has evolved and followed its own guidelines.

Finally, Luisa $\mathrm{M}^{\mathrm{a}}$ Serrano Patón, in The School of Translators of Toledo and the identification of Gundisalvo's main contributor, takes us into another quite unexplored area: the history of PST. First, she introduces the School of Translators of Toledo, one of the first European institutions to perform translations that could be considered as examples of PST; then, she investigates the identity of one of its most mysterious translators: the main contributor to the significant translator Gundisalvo, through the analysis of documents found in the library of the School of Translators itself and the Cathedral Archive of Toledo.

\section{References}

Angelelli, C. 2008. "The role of the interpreter in the healthcare setting: A plea for a dialogue between research and practice". Valero-Garcés, C. and Martin, A. (eds.). Crossing Borders in Community Interpreting. Definitions and dilemmas. Amsterdam/Philadelphia: Benjamins: 147-164.

Bolden, G. 2000. "Toward understanding practices of medical interpreting: interpreters' involvement in history taking". Discourse Studies, 2(4): 387-419.

Brunette, L., Bastin, G., Hemlin, I. and Clarke, H. (eds.) 2003. The Critical Link 3: Interpreters in the Community. Selected papers from the Third International Conference on Interpreting in Legal, Health and Social Service Settings. Montreal. Quebec. Canada. 22-26 May 2001. Benjamins Translation Library, 46. 
Cabré, T. 2004. "La terminología en la traducción especializada". García, C. and García Yebra, V. (eds.). Manual de documentación y terminología para la traducción especializada. Madrid: Arcos: 89-126.

Carr, S., Roberts, R., Dufour, A. and Steyn, D. (eds.) 1997. The Critical Link: Interpreters in the Community: Papers from the 1st international conference on interpreting in legal, health and social service settings. Geneva Park. Canada. 1-4 June 1995. Benjamins Translation Library, 19.

Ertl, A. \& Pöllabauer, S. 2010. "Training (Medical) Interpreters-the Key to Good Practice. MedInt: A Joint European Training Perspective". Jostrans, 7.

Hale, S., Ozolins, U. and Stern, L. (eds.) 2009. "The Critical Link 5: Quality in interpreting a shared responsibility". Benjamins Translation Library, 87.

Niska, H. 2003. "Cuando fracasan las palabras. Métodos y herramientas del trabajo terminológico para intérpretes en los servicios públicos". Valero-Garcés, C. (ed.). Traducción e Interpretación en los Servicios Públicos. Contextualización, actualidad y futuro. Granada: Comares: 91-124.

Nord, C. 1997. Translating as a Purposeful Activity. Manchester: St Jerome Publishing.

Roberts, R. 1997. "Community interpreting today and tomorrow". The Critical Link 1: interpreters in the community. Carr, S. et al. (eds.). Amsterdam/Philadelphia: John Benjamins: 7-28.

Roberts, R., Carr, S. Abraham, D. and Dufour, A. (eds.) 2000. The Critical Link 2: Interpreters in the Community. Selected papers from the Second International Conference on Interpreting in legal, health and social service settings. Vancouver. BC. Canada. 19-23 May 1998. Benjamins Translation Library, 31.

Schäffner, Ch., Kredens, K. and Fowler, Y. (eds.) 2013. Interpreting in a Changing Landscape: Selected papers from Critical Link 6. Benjamins Translation Library, 109.

Tomozeiu, D. 2014. "Challenges in defining 'community' for community translation University of Westminster". Conference Translating cultures: translation as a tool for inclusion/exclusion in a multicultural society. Westmister University. 20 June.

Valero-Garcés, C. 2002. "Traducir de y para los que llegan: una incipiente realidad en la España de principios del siglo XXI". Valero Garcés, C. and Mancho, G. (eds.). Traducción e Interpretación en los Servicios Públicos: Nueva necesidades para nuevas realidades. Community Interpreting and Translating; New Needs for New Realities. Alcalá de Henares: Servicio de Publicaciones de la Universidad.

Valero-Garcés, C. (ed.) 2005. Traducción como mediación entre lenguas y culturas / Translation as Mediation or how to Bridge Linguistic and Cultural Gaps. Alcalá de Henares: Servicio de Publicaciones de la Universidad.

Valero-Garcés, C., (ed.) 2008. Investigación y práctica en Traducción e Interpretación en los Servicios Públicos: desafíos y alianzas / Research and Practice in Public Service Interpreting and Translation: Challenges and Alliances. Alcalá de Henares: Servicio de Publicaciones de la Universidad.

Valero-Garcés, C., (ed.) 2011. Traducción e Interpretación en los Servicios Públicos en un mundo INTERcoNEcTado (TISP en INTERNET) / Public Service Interpreting 
and Translation in a Wild Wired World (PSIT in www). Alcalá de Henares: Servicio de Publicaciones de la Universidad.

Valero-Garcés, C., and Mancho, G. (eds.) 2002. Traducción e Interpretación en los Servicios Públicos: Nueva necesidades para nuevas realidades. Community Interpreting and Translating / New Needs for New Realities. Alcalá de Henares: Servicio de Publicaciones de la Universidad.

Valero-Garcés, C. y Sales, D. 2007. "The Production of Translated Texts for Migrant Minority Communities". Jostrans, 7. [Available at: http://www.JOSTRANS.org/issue07/issue07toc.htm].

Valero-Garcés, C.; Gauthier, L.; Megdiche, Ch and Vitalaru, B. 2011. "Traducción, lenguas de la inmigración y recursos online”. Hermeneus, 13: 209-232.

Valero-Garcés, C., Vitalaru, B., Mojica-López, E. (eds.) 2014. (Re)considerando ética e ideología en situaciones de conflicto/ (Re)visiting ethics and ideology in situations of conflicto. Alcalá de Henares: Servicio de Publicaciones de la Universidad.

Wadensjö, C., Englund, B. and Nilsson, A. (eds.) 2007. The Critical Link 4: Professionalisation of interpreting in the community. Selected papers from the 4th International Conference on Interpreting in Legal, Health and Social Service Settings. Stockholm. Sweden. 20-23 May 2004. Benjamins Translation Library, 70. 


\title{
EL EDITOR
}

\section{INTRODUCCIÓN \\ REFLEXIONES SOBRE LA TRADUCCIÓN EN LOS SERVICIOS PÚBLICOS}

\author{
Carmen Valero-Garcés \\ Universidad de Alcalá, España \\ carmen.valero@uah.es
}

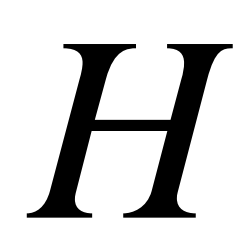

ace ya más de una década (2002) que en un artículo titulado "Traducir de y para los que llegan: una incipiente realidad”, (Valero-Garcés, 2002) hablábamos de la falta de interés y de estudios relevantes sobre la traducción entendida ésta como el traslado por escrito de un texto en una lengua a otra-, dentro del emergente campo por aquel entonces de la Traducción e Interpretación en los Servicios Públicos (TISP) (o Community Interpreting). Decíamos que se trataba de un área descuidada frente al interés por la interpretación en publicaciones, seminarios, talleres o comunicaciones en congresos específicos como Critical Link. La situación no parece haber cambiado demasiado a tenor de los comentarios de investigadores y formadores y del esfuerzo de unos y de otros para llamar la atención sobre este punto. Basta consultar la serie de publicaciones derivadas de los congresos de Critical Link (Brunette et al., 2003; Wadensjö et al., 2007; Hale et al., 2009; Schäffner et al., 2013) o de los congresos organizados por el grupo FITISPos en estos años (Valero Garcés et al., 2002, 2005, 2008, 2011, 2014).

La idea de dedicar el volumen 2 de FITISPOs IJ a un tema poco explorado y con escasos materiales parte precisamente de esta situación y ciertos elementos que llamaron nuestra atención en su momento. En primer lugar, la puesta en marcha de dos asociaciones directamente relacionadas con TISP, European Network in Public Service Interpreting and Translation (ENPSIT) (en español, Red Europea sobre Traducción e Interpretación en los Servicios Públicos) y la Asociación de Formadores, Investigadores y Profesionales en Traducción e Interpretación en los Servicios Públicos (AFIPTISP) en las que se incluía el término "traducción".

En segundo lugar, el patrocinio por parte de la Comisión Europea de la Jornada Traducción e interpretación para nuestros ciudadanos (marzo de 2014), que reunió por primera vez a la Dirección General de Traducción (EU-DGT), la Dirección General de Interpretación (DG Interpretation, $S C I C)$ y a los diferentes agentes que participan en el mantenimiento del multilingüísmo. El objetivo era crear sinergias y dar un paso más en su política de comunicación con las lenguas de menos difusión fueran o no europeas.

En tercer lugar, la celebración de varios eventos marcadamente centrados en la traducción. Me refiero a las dos congresos organizados por un lado, en la Universidad de Westmister (University of Westminster), Londres, Reino Unido, bajo el lema Translating cultures: translation as a tool for inclusión / exclusion in a multicultural society ('Traducir culturas: la traducción como herramienta para la inclusión/exclusión en una sociedad multicultural') en junio de 2014 y por otro lado, en la Universidad de Western Sydney, Australia, bajo el tema "Community Translation" ('Traducción en los Servicios Públicos') en septiembre de 2014. 
Los temas principales que figuraban en los congresos de Sydney y Reino Unido llaman ya la atención sobre la complejidad de la traducción y de la variedad de estudios por realizar: política lingüística y Traducción en los Servicios Públicos (TSP); traducción e inclusividad; diversidad sociocultural y traducción; ideología y TSP; relaciones de poder: traducir vs. empoderamiento; traducir desde y hacia las lenguas minoritarias; calidad de la traducción en los servicios públicos o formación en TSP. Y los títulos de algunos de los trabajos presentados dan cuenta de este interés y de la necesidad de seguir investigando en la TSP:

- "Translation as a communication tool in the police environment" ("La traducción como herramienta de comunicación en el entorno de la policía') (Katrina Mayfield);

- "Challenges in defining "community" for community translation" ("Desafíos en la definición de "comunidad" para la traducción en los servicios públicos’) (Daniel Tomozeiu);

- "Community translation: an examination of practice and praxis" ('La traducción en los servicios públicos: un examen de la práctica y de la praxis’) (Brooke Townsley);

- "Language policy and public service translation: the case of European multilingualism" ('La política lingüística y la traducción en los servicios públicos: el caso del multilingüismo europeo') (Catherine Vieilledent-Monfort);

- "Translation and language ideologies" ('Traducción e ideologías lingüísticas') (Abigail Pita).

El principal objetivo de la TSP es comunicar directamente información específica (sobre temas de salud, educativos, administrativos, sociales, etc.) a un público también específico: un público - como ocurre también en el caso de la interpretación- que responde a una minoría cultural y lingüística, que posee un nivel educativo y adquisitivo generalmente inferior al de la mayoría y que, con frecuencia, desconoce o no domina la nueva realidad social del país en el que se encuentra. Además, tal y como Roberts (1997:12) indicaba, la cultura del grupo minoritario - e incluso más que la lengua- no es siempre comprendida por el grupo mayoritario que es el que organiza y ofrece los servicios a dicho cliente. En otras palabras, su objetivo es adaptar un texto a las necesidades de una minoría que convive en un país con la mayoría dominante (Valero Garcés, 2002: 63).

Tomozeiu (2014) da una definición similar para al final añadir dos líneas relevantes sobre la importancia de otros elementos no siempre tenidos en cuenta como son el qué y el cómo se traduce:

'Public service translation' (also known as 'Community translation') is emerging as an important, distinct subfield in translation studies. Its focus on the translation of texts produced by public services for the benefit of speakers of less-established languages makes it a particularly relevant research area in today's globalising world. In a multicultural society decisions about what is translated and how the translation is done have far-reaching implications for the inclusion and

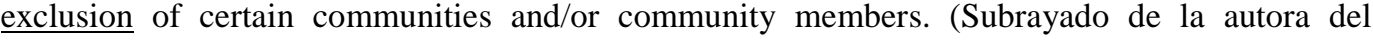
artículo).

[La traducción en los servicios públicos (también conocida como 'traducción comunitaria) se está convirtiendo en un subcampo importante distinta en los Estudios de Traducción. Su enfoque en la traducción de textos producidos por los servicios públicos en beneficio de los hablantes de lenguas menos establecidas hace que sea un área de investigación especialmente relevante en el mundo globalizado de hoy en día. En la sociedad multicultural las decisiones sobre lo que se traduce y cómo se realiza la traducción tiene implicaciones de largo alcance para la inclusión y la exclusión de ciertas comunidades y / o miembros de la comunidad] (Traducción propia). 
La consideración de dichos elementos nos lleva a pensar en el iniciador del proceso de la traducción (quién solicita esa traducción) y en el ejecutor de la acción misma (el traductor) (Nord, 1997). En cuanto al primer punto, suele coincidir con el proveedor de servicios, y son las instituciones, ONGs, asociaciones, oficinas gubernamentales, hospitales, centros educativos, etc. los que solicitan la traducción de una gran variedad de textos de naturaleza y complejidad bien distinta (desde una partida de nacimiento a un contrato de alquiler, por poner algún ejemplo). Ello tiene también consecuencias para el traductor, tal y como veremos a continuación.

La literatura sobre la TISP ofrece ejemplos de la labor del intérprete (Bolden, 2000; Angelelli, 2004; Erlt y Pöllabauer, 2010). Sin embargo, apenas encontramos estudios sobre el traductor y de nuevo surgen las preguntas: ¿Es el traductor un mediador socio-cultural con habilidades específicas y preparación adecuada que van más allá del conocimiento de las lenguas (o dialectos) y culturas? ¿Se requiere un buen desarrollo de la competencia intercultural? ¿Por qué? ¿Cómo influye el trabajar con dos lenguas una de las cuales suele poseer un estatus social inferior frente a la otra que pertenece a la cultura dominante? ¿Cómo garantizar cierta neutralidad y distancia incluso cuando se trabaja para su misma comunidad étnica? ¿Cómo ser consciente de la falta de educación o de las diferencias culturales entre ambas comunidades? ¿Cómo desarrollar estrategias para servir de puente lingüístico y cultural a la hora de tratar temas específicos que pueden ser tabúes para alguna de las comunidades? ¿Debe conocer terminología específica relacionada con los temas de trabajo? ¿Qué tipo de textos debe traducir? ¿Si el objetivo es comunicar, debe ser capaz de cambiar de registro o adaptar el texto según las necesidades de la comunidad receptora?, etc.

El traductor debe también luchar contra el escaso reconocimiento del que goza dicha profesión; ello lleva a ser un trabajo mal remunerado que impide a sus practicantes, con frecuencia, acceder a la escasa formación disponible. Sorprende que, a pesar del gran número de centros formativos en traducción (solo en España hay más de una docena de Facultades de Traducción e Interpretación) haya tan pocas opciones formativas relacionadas con esta subárea de los Estudios de Traducción, la TSP. Ello nos lleva a otra pregunta: ¿Puede ser considerada la TSP como traducción específica?

Las diferencias entre la traducción especializada y la general son, según Monterde Rey (2003: 107), las siguientes:

1. En la traducción especializada el emisor y el receptor del texto pertenecen a un lenguaje de especialidad.

2. El traductor debe conocer (o ser capaz de encontrar) la terminología que se utiliza.

3. El traductor debe conocer (o ser capaz de documentarse) sobre el tema especializado que va a tratar.

Estamos de acuerdo con dichas características siempre y cuando estemos hablando de traductores/ intérpretes profesionales. En el caso de la TSP, no cabe duda de que en esta búsqueda de la comunicación entre participantes tan distintos, el traductor trabaja con textos especializados (p. ej. tratamiento médico), en situaciones complejas (p. ej solicitud de empadronamiento) y debe ser, por lo tanto, polifacético (p. ej. dominar el lenguaje y las convenciones sociales o de tipología textual de los hablantes). y de nuevo surgen más preguntas: ¿qué ocurre cuando se trata de traductores / intérpretes ad hoc voluntarios y sin formación? ¿Cómo manejan la terminología? ¿A qué tipo de documentación tienen acceso? ¿Qué estrategias usan para verter el concepto o expresión a la lengua meta? ¿Qué fiabilidad ofrece su trabajo? ¿Es necesaria una preparación especial? ¿Qué ocurre cuando, una vez detectados los problemas, no se dispone de documentos paralelos, expertos a los que consultar o diccionarios y bancos terminológicos? ¿Cómo manejan ese lenguaje 
especializado los voluntarios y familiares de los clientes que ejercen como traductores /intérpretes en nuestros hospitales, centros de salud, comisarías de policía o colegios? ¿Existen recursos especializados en las lenguas minoritarias para cubrir esas necesidades?

Tres son los marcos principales donde la terminología / lenguajes específicos se usan en la comunicación:

$$
\begin{aligned}
& \text { experto }-><- \text { experto } \\
& \text { experto }-><- \text { inexperto } \\
& \text { inexperto }-><\text { - inexperto }
\end{aligned}
$$

A este binomio puede añadirse un tercer elemento cuando los hablantes no comparten las lenguas y en ese caso nos podemos encontrar con las siguientes situaciones tripartitas:

$$
\begin{aligned}
& \text { experto }-><\text { - mediador }-><\text { - experto } \\
& \text { experto }-><- \text { mediador }-><\text { - inexperto } \\
& \text { inexperto- }-<- \text { mediador }-><\text { - inexperto }
\end{aligned}
$$

En el campo de la TISP es muy habitual la comunicación entre un experto y un inexperto; por ejemplo, una consulta médica en la que participan el médico, un paciente casi analfabeto que no conoce el español y el mediador o tercer elemento que hace posible la comunicación y que debe hacer una traducción de un folleto con información sobre como un tratamiento de úlcera de estómago.

El lenguaje especializado, o llamémosle terminología, nos rodea en nuestra vida diaria. Lo encontramos en cualquier documento escrito de un campo especializado dirigido a expertos: artículos en revista científicas; pero también en textos dirigido a inexpertos en ese campo: informes de solicitudes de empadronamiento, demandas judiciales, expedientes académicos, contratos laborales o folletos explicativos entre otros.

Teresa Cabré (2004: 101-102) deja claro igualmente que es imposible trazar una línea divisoria nítida entre la noción de lo que es general o especializado. Y da tres razones precisas:

1. Porque las actividades cotidianas de la mayoría de los individuos se desenvuelven siempre en ámbitos especializados, aunque ese carácter cotidiano favorezca que la especialización pase desapercibida.

2. Porque se da un trasvase permanente entre la vida común y la especializada, con la consiguiente aparición de dos fenómenos contrapuestos en el léxico que se utiliza para referirse a la realidad: el traslado de unidades del léxico general al especializado (terminologización) y el traslado de términos especializados al general (banalización).

3. Porque un tema puede tratarse a distintos niveles de abstracción, con distintos propósitos comunicativos, en distintas situaciones de comunicación y para distintas funciones lingüísticas. $\mathrm{Y}$ no en todos los casos resulta ser un texto especializado (Cabré, 2004: 102).

Y de nuevo surgen más preguntas: ¿Qué ocurre cuando, una vez detectados los problemas, no se dispone de documentos paralelos, expertos a los que consultar o diccionarios y bancos terminológicos? ¿Qué estrategias se usan para verter el concepto o expresión a la lengua meta y cómo se maneja la terminología y la documentación? Tanto la población extranjera como los proveedores de servicios en sus contactos hacen uso de frases y términos especiales que el traductor tiene que entender y traducir para asegurar que la 
información se traslada correctamente. Muy a menudo, esta terminología no se encuentra en diccionarios comunes - de hecho, puede que no exista ningún diccionario entre el idioma mayoritario y el idioma hablado por la minoría (Valero Garcés et al, 2011). El traductor debe recurrir entonces a las mismas estrategias que el traductor especializado, es decir, la omisión, el uso de una equivalencia "aproximada" o "provisional", la explicación del concepto, el préstamo o la creación de palabras nuevas (Niska, 2003). En definitiva, podríamos decir que la TSP es un caso híbrido y complejo de traducción especializada en el que confluyen factores muy diversos y que, al igual que en toda especialización, requiere de especialistas y formación adecuada.

En resumen, quedan muchos temas por explorar y trabajos de investigación que publicar sobre la traducción en los servicios públicos. Esperemos que el volumen 2 de FITISPos-IJ ayude a rellenar ese vacío que existe en el campo de la TISP y contribuya a dar mayor visibilidad a esta área emergente de los Estudios de Traducción. Haciéndose igualmente eco de su carácter multilingüe incluye artículos en español, inglés, ruso y chino. Conscientes de esta diversidad de temas y enfoques se incluyen ocho artículos ordenados alfabéticamente según el nombre del primer autor.

El primer capítulo se debe a Ineke Creeze y Hanneke Lustig y, bajo el título A look inside the translators' workspace: Discussions around a large nursing text translation/ Una inmersión en el espacio de trabajo del traductor. Análisis de la traducción de un libro de texto de enfermería. Debate en torno a la traducción de un extenso texto de enfermería'), investiga los retos que supone la traducción de textos, en este caso de temas de enfermería, para comunidades diferentes y distantes en cuanto al tiempo de trabajo (Nueva Zelanda y Holanda). Se basa fundamentalmente en la teoría del skopos y propuestas para la traducción de términos culturales.

Ula Idzikowska, en el segundo artículo, titulado Public Service Translation in Flanders: On the continuous efforts to evolve from paraprofessionalism to professionalism/Traducción en los Servicios Públicos: Los esfuerzos continuos por evolucionar de la paraprofesionalidad a la profesionalidad, nos ofrece la descripción de los pasos seguidos hasta ahora en Flandes (Bélgica) para avanzar en el reconocimiento de la traducción en los servicios públicos como una profesión y de lo que queda aún por hacer, consciente de la poca atención que se le ha prestado a este tema dentro de la TISP, y muy en línea con lo dicho en las páginas anteriores.

Ivona Ivanova Angelova, en el tercer artículo, bajo el título de Introducción al concepto de tortura como punto de partida para una base de datos (inglés-español), trata un tema que aunque puede parecer ajeno a primera vista a la traducción en los servicios públicos no lo es en tanto en cuanto de todos es sabido que los traductores y los intérpretes en este ámbito deben trabajar en contextos muy diferentes y entrar en contacto con personas susceptibles de haber sufrido algún tipo de tortura como puede ser en el entorno de asilo y refugio o en el ámbito policial. El artículo introduce al lector en el concepto de la tortura con pinceladas sobre su evolución histórica, tipos de prácticas y lugares en los que se ejerció como base para una primera propuesta de glosario terminológico (inglés-español), llamando así la atención sobre la falta de estos recursos.

En el artículo cuarto, Mengshuan Ku nos lleva a otro entorno bien distinto (Taiwán) y en otra lengua (chino) como ejemplo de esa diversidad de temas en la TSP. Bajo el título 台北捷運營運資訊簡介」西班牙語版分析l Análisis de la traducción de la 'Guía del Metro de Taipei' en su versión española, $\mathrm{Ku}$ estudia el contexto plurilingüístico de los servicios públicos de Taiwán, y compara la versión en chino y la española de esta guía desde la perspectiva de un hablante hispanohablante en Taiwán y la aceptabilidad del texto, teniendo en cuenta que la prosperidad económica de este país le convierte en un potencial receptor de población inmigrante. 
Maneerat Marnpae, en el artículo cinco, titulado La traducción funcionalista en los servicios públicos: un caso de materiales de apoyo del ámbito sanitario para la población inmigrante, se sirve de las teorías funcionalista para defender la idea de la necesaria incorporación de las expectativas del receptor y de la cultura meta para producir textos más eficaces en los servicios públicos. Utiliza para ello el análisis de materiales de apoyo relativos a la salud pública y la orientación sociosanitaria en español para el público tailandés.

Araceli Rojo Chacón, a través de La transposición al derecho nacional de la Directiva europea 2010/64/UE en España, Francia, Bélgica y Luxemburgo: 'Lost in transposition', nos lleva al ámbito legal para mostrar un estudio comparativo de la situación de los traductores jurídicos en dichos países tomando como modelo el sistema austríaco establecido antes de la Directiva 2010/64/UE. El estudio muestras las diferencias y los retos a los que se están enfrentando los distintos países para la transposición de la Directiva en temas como la creación de registro de traductores para actuar en los procesos penales.

Además, Maria Shcherbakova, en su artículo en ruso titulado Концептуальный подход к разработке глоссария по медицинской терминологии (русско-испанский)/ Enfoque conceptual aplicado en la elaboración de un glosario sobre terminología médica (ruso-español), se centra en el trabajo terminológico en el ámbito médico entre dos lenguas (ruso-español) en las que escasean los recursos traductológicos. El objetivo es la creación de un glosario de la terminología del sistema cardiovascular precedido de un análisis exhaustivo de la traducción de términos realizada con comentarios que pueden prevenir errores y confusiones entre los traductores y recipientes de la información traducida. Ello le permite comprobar su hipótesis de partida de que, a pesar del origen griego y latín de la mayoría de los términos seleccionados en español y una gran parte de los términos en ruso, la traducción literal de éstos representa el error más grave y más frecuente de los traductores de los textos médicos ya que debido a las peculiaridades del desarrollo de los sistemas de lenguajes médicos en español y en ruso, la terminología de cada idioma ha seguido sus propias pautas de evolución.

Finalmente, Luisa M $\mathrm{M}^{\mathrm{a}}$ Serrano Patón, en The School of Translators of Toledo and the Identification of Gundisalvo's Main Contributor/ La Escuela de Traductores de Toledo y la identificación de las principales contribuciones de Gundisalvo, nos adentra en otro ámbito en el que queda también mucho por hacer: la historia de la TSP. Elige para ello la Escuela de Traductores de Toledo, una de las primeras instituciones europeas en realizar traducciones que podrían ser consideradas como ejemplos de traducciones de los Servicios Públicos, para buscar la identidad de uno de sus traductores más relevantes: el colaborador principal de Gundisalvo. Se sirve para ello del análisis de documentos encontrados en la actual biblioteca de la Escuela de Traductores de Toledo y en el Archivo Catedralicio de Toledo.

\section{Referencias bibliográficas}

Angelelli, C. 2008. "The role of the interpreter in the healthcare setting: A plea for a dialogue between research and practice". Valero-Garcés, C. y Martin, A. (eds.). Crossing Borders in Community Interpreting. Definitions and dilemmas. Amsterdam/Philadelphia: Benjamins, 147-164.

Bolden, G. 2000. "Toward understanding practices of medical interpreting: interpreters' involvement in history taking". Discourse Studies, 2 (4): 387-419.

Brunette, L., Bastin, G., Hemlin, I. y Clarke, H. (eds.) 2003. The Critical Link 3: Interpreters in the Community. Selected papers from the Third International 
Conference on Interpreting in Legal, Health and Social Service Settings. Montreal. Quebec. Canada. 22-26 mayo 2001. Benjamins Translation Library, 46.

Cabré, T. 2004. "La terminología en la traducción especializada". García, C. y García Yebra, V. (eds.) Manual de documentación y terminología para la traducción especializada. Madrid: Arcos: 89-126.

Carr, S., Roberts, R., Dufour, A. y Steyn, D. (eds.) 1997. The Critical Link: Interpreters in the Community: Papers from the 1st international conference on interpreting in legal, health and social service settings. Geneva Park. Canada. 1-4 Junio 1995. Benjamins Translation Library, 19.

Ertl, A. y Pöllabauer, S. 2010. "Training (Medical) Interpreters-the Key to Good Practice. MedInt: A Joint European Training Perspective". Jostrans, 7.

Hale, S., Ozolins, U. y Stern, L. (eds.) 2009. The Critical Link 5: Quality in interpreting - a shared responsibility. Benjamins Translation Library, 87.

Niska, H. 2003. "Cuando fracasan las palabras. Métodos y herramientas del trabajo terminológico para intérpretes en los servicios públicos". Valero-Garcés, Carmen (ed.). Traducción e Interpretación en los Servicios Públicos. Contextualización, actualidad y futuro. Granada: Comares: 91-124.

Nord, Ch. 1997. Translating as a Purposeful Activity. Manchester: St Jerome Publishing.

Roberts, R. 1997. "Community interpreting today and tomorrow". The Critical Link 1: interpreters in the community. Carr, S. et al. (eds.). Amsterdam/Philadelphia: John Benjamins: 7-28.

Roberts, R., Carr, S. Abraham, D. y Dufour, A. (eds.) 2000. The Critical Link 2: Interpreters in the Community. Selected papers from the Second International Conference on Interpreting in legal, health and social service settings. Vancouver. BC. Canada. 1923 mayo 1998. Benjamins Translation Library, 31.

Schäffner, Ch., Kredens, K. y Fowler, Y. (eds.) 2013. Interpreting in a Changing Landscape: Selected papers from Critical Link 6. Benjamins Translation Library, 109.

Tomozeiu, D. 2014. "Challenges in defining 'community' for community translation University of Westminster". Conferencia Translating cultures: translation as a tool for inclusion/exclusion in a multicultural society. Universidad de Westmister. 20 junio.

Valero-Garcés, C. 2002. "Traducir de y para los que llegan: una incipiente realidad en la España de principios del siglo XXI". Valero Garcés, C. y Mancho, G. (eds.). Traducción e Interpretación en los Servicios Públicos: Nueva necesidades para nuevas realidades. Community Interpreting and Translating; New Needs for New Realities. Alcalá de Henares: Servicio de Publicaciones de la Universidad.

Valero-Garcés, C. (ed.) 2005. Traducción como mediación entre lenguas y culturas / Translation as Mediation or how to Bridge Linguistic and Cultural Gaps. Alcalá de Henares: Servicio de Publicaciones de la Universidad.

Valero-Garcés, C. (ed.) 2008. Investigación y práctica en Traducción e Interpretación en los Servicios Públicos: desafíos y alianzas / Research and Practice in Public Service Interpreting and Translation: Challenges and Alliances. Alcalá de Henares: Servicio de Publicaciones de la Universidad.

Valero-Garcés, C. (ed.). 2011. Traducción e Interpretación en los Servicios Públicos en un mundo INTERcoNEcTado (TISP en INTERNET) / Public Service Interpreting and Translation in a Wild Wired World (PSIT in www). Alcalá de Henares: Servicio de Publicaciones de la Universidad.

Valero-Garcés, C., y Mancho, G. (eds.) 2002. Traducción e Interpretación en los Servicios Públicos: Nueva necesidades para nuevas realidades. Community Interpreting and 
Translating / New Needs for New Realities. Alcalá de Henares: Servicio de Publicaciones de la Universidad.

Valero-Garcés, C. y Sales, D. 2007. "The Production of Translated Texts for Migrant Minority Communities". Jostrans, 7. [Disponible en: http://www.JOSTRANS.org/issue07/issue07toc.htm]

Valero-Garcés, C.; Gauthier, L.; Megdiche, Ch y Vitalaru, B. 2011. "Traducción, lenguas de la inmigración y recursos online". Hermeneus, 13: 209-232.

Valero-Garcés, C., Vitalaru, B., Mojica-López, E. (eds.). 2014. (Re)considerando ética e ideología en situaciones de conflicto/ (Re)visiting ethics and ideology in situations of conflicto. Alcalá de Henares: Servicio de Publicaciones de la Universidad.

Wadensjö, C., Englund, B. y Nilsson, A. (eds.) 2007. The Critical Link 4: Professionalisation of interpreting in the community. Selected papers from the 4th International Conference on Interpreting in Legal, Health and Social Service Settings. Stockholm. Sweden. 20-23 mayo 2004. Benjamins Translation Library, 70. 